Food, Dairy and Home Economic Research

Available online at http://zjar.journals.ekb.eg

http:/www.journals.zu.edu.eg/journalDisplay.aspx?Journalld=1\&queryType=Master

\title{
ANTIMICROBIAL RESISTANCE AND BIOFILM FORMATION PATTERNS OF Escherichia coli ISOLATED FROM MARKET RAW MILK AT ZAGAZIG CITY
}

\author{
Aya R. Mohammed*, Esmat I. El-Said, S.F. Abd El-Aal and Rania M. Kamal \\ Food Control Dept., Fac. Vet. Med., Zagazig Univ., Egypt
}

Received: 27/02/2021 ; Accepted: 09/03/2021

\begin{abstract}
In the present study, one hundred samples of raw cow milk were collected randomly from different dairy shops and markets in Zagazig city for isolation and identification of Escherichia coli which is considered a reliable indicator for fecal contamination and an important cause of food poisoning. Identification was done microscopically, biochemically by different biochemical tests (IMVIC) and serologically. The incidence of E. coli in raw milk samples was $47 \%$. Also, the serological identification of $E$. coli isolates revealed that $\mathrm{O} 26$ is the most predominant serogroup by percentage of $21.3 \%$. E. coli pose the greatest threat to human health because of its growing resistance to antibiotics. Antimicrobial susceptibility testing (AST) was done by disc diffusion method against 10 antimicrobials and the results revealed that $E$. coli isolates were highly resistant to amoxicillinclavulanate, ampicillin, cefotaxime and ceftazidime with percentages of $89.4 \%, 89.4 \%, 100.0 \%$ and $100.0 \%$, respectively. However, they were highly sensitive to chloramphenicol, ciprofloxacin and tetracycline with percentage of $100.0 \%, 100.0 \%$ and $93.6 \%$ respectively. In addition, $89.4 \%$ of $E$. coli isolates showed multi drug resistance (MDR). The ability of bacteria for adherence to food surfaces and biofilm formation is a source of food contamination that affect food safety and industry. Micro titer plate assay used for testing biofilm formation and represented that $78.7 \%$ of E. coli isolates were non-biofilm producers, $6.4 \%$ were weak biofilm producers, $14.9 \%$ were moderate biofilm producers and none of isolates was strong biofilm producers.
\end{abstract}

Key words: $E$. coli, raw milk, antimicrobial resistance, biofilm.

\section{INTRODUCTION}

Milk ranks high among other foods and is considered as the most perfect food for human from birth to senility as it is not only has good sensory properties and all nutrients required for the body for rapid growth but also could prevent or reduce risks of many nutritional deficiency diseases (Kalkwarf et al., 2003; Marshall et al., 2003).

Raw milk is still used by large number of farm families and workers and by a growing segment of the general population who believe that the milk is not only safe but also imparts beneficial health effects that are destroyed by pasteurization (Angulo et al., 2009).
Due to its high nutritious content, milk allows the growth of a copious number of microorganisms. Therefore, apart from its endogenous microbiota, diverse and numerous other microorganisms originating from the teat canal, udder skin, milking machines, tanks, and containers used to store it, reflecting the farm and the pasture environment as well, might colonize the milk as soon as it has been milked (Addis et al., 2016).

Among all micro-organisms Escherichia coli is frequently contaminating organism in food and is reliable indicator of fecal contamination and generally present due to insanitary conditions of water, food, milk and other dairy products (Jayarao and Henning, 2001).

* Corresponding author: Tel.: +201013376729

E-mail address: ayareiad@zu.edu.eg 
Antibiotic resistance is a seemingly growing problem in both developing and developed countries of the world. The rise in the use of antibiotics in human medicine, veterinary medicine and agriculture has been contributory to the rapid rise of antibiotic resistance among bacterial species especially and this has increased the challenge of multidrug-resistant bacteria in the environment (Reinthaler et al., 2010; Xu et al., 2014).

The emergence and dissemination of multidrug-resistant (MDR) bacterial species have been associated with the extensive use of broad-spectrum antimicrobials in treating human and animal infections (Rzewuska et al., 2015). In animal husbandry, antibiotics are used as animal growth promoters and are regularly abused for the prevention and treatment of animal infections (Nepal and Bhatta, 2018). All these together contribute to the development of bacterial resistance to antibiotics. Genetic factors such as horizontal gene transfer and clonal expansion of resistant isolates also play a crucial role in the acquisition of antibiotic resistance traits in bacteria (Peterson and Kaur, 2018).

A biofilm is defined as an organized collection of surface attached microbial communities of cells that are embedded into a self-produced exopolymeric matrix mainly composed of proteins, polysaccharides and sometimes DNA (Hall-Stoodley et al., 2004). The formation of biofilm is a result of different stress condition(s) where biofilms acts as a defense mechanism enhancing the survival rate of microorganism. They play an important role in microbial pathogenesis and persistence as well as serve as grounds for genetic exchanges. It acts as shield protecting the microbial community from action of various antimicrobial agents such as antibiotics, preservatives, chemical sanitizers, thermal treatment etc. that are traditionally used in food industry, thus making them robust and hard to eradicate (Monte $\boldsymbol{e t}$ al., 2014). The biofilm formation for many bacterial species including E. coli occurs as early as two hours and they can survive up to ten years in food industries despite the regular cleaning and sanitation treatment (Corcoran et al., 2014).

This study was undertaken to determine the occurrence and characteristics of E.coli strains in market raw cow milk at Zagazig city and to estimate the potential of these sources acting as vehicles of antimicrobial resistance.

\section{MATERIALS AND METHODS}

\section{Samples Collection and Preparation}

One hundred random samples of raw milk were collected from different dairy shops and markets in Zagazig city, Sharkia Governorate, Egypt under hygienic condition during the period from February to August 2020. Approximately $500 \mathrm{ml}$ of the samples were transferred to the laboratory of Food Control Department, Faculty of Veterinary Medicine, Zagazig University in an insulated icebox with a minimum of delay to be examined microbiologically.

\section{Isolation and Identification of $\boldsymbol{E}$. coli}

Eleven $\mathrm{ml}$ of well-mixed samples were aseptically transferred into a sterile bottle containing $99 \mathrm{ml}$ of sterile buffered peptone water (BPW) to make a dilution of $1: 10$ and incubated at $37^{\circ} \mathrm{C}$ for $24 \mathrm{hrs}$. A loopful of the BPW enrichment was streaked on Eosin Methylene Blue agar (EMBA; Oxoid) and then incubated at $37^{\circ} \mathrm{C}$ for $24 \mathrm{hrs}$. The agar plates were examined for growth of $E$. coli. To get pure cultures, a single colony was further subcultured on EMBA according to (Ngaywa et al., 2019)

Films of pure suspected cultures were stained with Gram's stain and examined microscopically. Cultures analyzed by using the following biochemical tests:

Indole Motility Test, Methyl Red, VogesProskauer Tests and Simmons Citrate Agar Test according to APHA. (2004)

\section{Serological Identification of Isolated $E$. coli}

The isolates were serologically identified by slide agglutination test according to Kok $\boldsymbol{e t} \boldsymbol{a l}$. (1996) using rapid diagnostic E. coli antisera sets (DENKA SEIKEN Co., Japan) to identify O antigen.

\section{Antimicrobial Susceptibility Testing}

Antimicrobial susceptibility testing (AST) was done using the Kirby-Bauer disc diffusion 
method on Mueller-Hinton agar (Oxoid, Hampshire, England) as described by the Clinical and Laboratory Standards Institute (CLSI, 2017). with an inoculum equivalent to $0.5 \mathrm{McF}$ arland standards. Incubation was done at $35 \pm 2^{\circ} \mathrm{C}$, ambient air, for $16-18 \mathrm{hrs}$. The following 10 antimicrobials were tested:

Amoxicillin/clavulanic acid, ampicillin, cefotaxime, ceftazidime, chloramphenicol, ciprofloxacin, kanamycin, Nalidixic acid, streptomycin and tetracycline

The sensitivity/resistance was interpreted based on the diameter zone of inhibition, inclusive of margins, following the Clinical Laboratory Standards Institute guidelines (CLSI, 2017). The isolates were classified as intermediate, susceptible or resistant (CLSI, 2017). In addition, we calculated the number of E. coli isolates that were considered multidrug resistant (MDR), that is, resistant to three or more antimicrobials of different classes (Frye and Fedorka-Cray, 2007) and the Multiple Antimicrobials Resistance index (MAR) for each $E$. coli isolate according to the methodology described by (Krumperman, 1983). This index shows the relationship between the number of resistant $E$. coli to each antimicrobial and the total number of classes tested.

\section{Biofilm Formation}

The biofilm formation test was performed as described by Stepanovic et al. (2000), where E. coli strains were incubated in TSB broth at 37 $\pm 1^{\circ} \mathrm{C}$ for $24 \mathrm{hrs}$. Then aliquots were diluted in a new tube until reaching the turbidity of one on the McFarland scale. Subsequently, $200 \mu \mathrm{L}$ of each suspension in triplicate were inoculated into a 96-well sterile polystyrene micro plates. In the first three wells, only sterile broth was added as a negative control. The plates were incubated without air circulation at $37 \pm 1^{\circ} \mathrm{C}$ for $24 \mathrm{~h}$. Next, the bacterial suspensions were aspirated from each well and washed three times with $250 \mu \mathrm{L}$ of sterile $0.9 \%$ sodium chloride solution. The bacterial cells were then fixed with $200 \mu \mathrm{L}$ of methanol (PA) for $15 \mathrm{~min}$ and dried at room temperature. Later, they were stained with $200 \mu \mathrm{L}$ of $2 \%$ Hucker crystal violet for 5 min, washed in running water and dried at room temperature. Re-solubilization was performed with $160 \mu \mathrm{L}$ of $33 \%$ glacial acetic acid followed by reading using a spectrophotometer (Thermo Scientific ${ }^{\circledR}$ Multiskan GO) at $570 \mathrm{~nm}$. After reading, the optical density value of each strain (OD) was obtained by calculating the arithmetic mean of the absorbance of the three wells, and this value was compared to three standard deviations above the mean of the absorbance of the negative control (ODC). The strains were classified in four different categories as follows: A) non-biofilm producer (OD $\leq \mathrm{ODC})$; B) weak biofilm producer (ODC $<\mathrm{OD} \leq 2 \times \mathrm{ODC})$; $\mathrm{C}$ ) moderate biofilm producer $(2 \times$ ODC $<$ OD $\leq 4$ $\times$ ODC $)$; and D) strong biofilm producer $(4 \times$ ODC < OD) (Stepanovic et al., 2000).

\section{RESULTS AND DISCUSSION}

\section{Incidence of E.coli in Market Raw Milk and Serological Identification of Isolates}

Milk, a perishable complete nutritious food is considered a good medium of growth for many of the microorganisms (Khayal and Ragia, 2013).

Conditions for contamination of raw milk at different critical points are due to less hygienic practices in pre-milking udder preparation, suboptimal hygiene of milk handlers, and poor sanitation practices associated with milking and storage equipment, higher environmental contamination during transportation or contamination during waiting along the roadside (Garedew et al., 2012)

There is an increasing in number of people whose consuming raw unpasteurized milk due to enhancing nutritional quality, taste and health benefits in spite of several documented milk born disease outbreaks occurred from consumption of raw unpasteurized milk and dairy products manufactured using raw milk (Leedom, 2006; Oliver et al., 2009).

In recent years, much attention has been paid toward E. coli because of its importance as an organism of true faecal origin with the possible existence of associated enteric pathogens. Commensal E. coli plays a dynamic role in the ecology of intestinal tract. The E. coli genome exhibits a high degree of heterogeneity; therefore, these bacteria can be a commensal organism. On the other hand, it can be also a dangerous pathogen causing intestinal or extraintestinal infections. It is of major public health 
significance related to risk of introducing these bacteria to the food chain (Newell et al., 2010).

Illness caused by entero-pathogenic E. coli can range from self-limited watery diarrhea to life threatening manifestations such as hemorrhagic colitis, hemolytic uremic syndrome, and thrombocytopenic purpura and may lead to death (Alexander and Prado, 2003).

The results presented in Table 1 revealed that, the incidence of E.coli in raw milk were 47\%. Meshref (2013) reported nearly similar results where he found E.coli by (52.6\%). The contamination rate in raw milk samples was extremely lower than the findings of Sobeih $\boldsymbol{e t}$ al. (2002), Soomro et al. (2002), Chye et al. (2004) and Altalhi and Hassan (2009) as they found $88,65,65$ and $66 \%$ of their samples were contaminated by E. coli, respectively, but higher than the rate of 32, 27.5,10 and 3.3\% reported by Ahmed and Sallam (1991), Mezyed et al.(2008), Tasci (2011) and El-Prince et al. (2010), respectively.

Table 2 illustrated the serological identification of isolated E. coli. The strains of E. coli isolated from examined raw milk samples were $\mathrm{O} 25$, O26,O44, O55, O78, O86, O114, O119, O125, O127, O158 and O168 by percentage of (10.6\%), (21.3\%), (8.5\%), (14.9\%), (4.3\%), (4.3\%), (6.4\%), $(6.4 \%),(8.5 \%),(4.3 \%),(4.3 \%)$ and $(6.4 \%)$ respectively. While nearly similar results were obtained by El-Nahas et al. (2015) who found $\mathrm{O} 114, \mathrm{O} 26$, and $\mathrm{O} 127$ in raw milk samples. Also El-Zamkan et al. (2018) isolated E. coli O26, O55 \& O119 from raw milk. Khafagy et al. (2017) isolated $\mathrm{O} 158, \mathrm{O} 55$, and $\mathrm{O} 86$ from raw milk samples obtained from dairy farms and shops. Rashid et al. (2013) reported the presence of one milk sample serologically identified as O86. El-bagory et al. (2016) and other researchers as; Lamey et al. (2013) and Abike et al. (2015) recorded for the identification of E.coli strain that belongs to the serogroup O55. Others as Wenz et al. (2006) and Koraney (2016) recorded O158, which is one of the frequent serogroups that isolated from raw milk samples. In addition, AbdEl-Maabud (2014) and Shalaby et al. (2019) isolated E. coli O26 from raw milk samples.

Globally, the unsupervised use of antimicrobial agents in the treatment of animal and human infections have been contributed to the emergence of antimicrobial resistance (Van Boeckel et al., 2015). The antimicrobial resistance mainly originates from the transfer of resistance genes across microbes enabling them to survive in the presence of antimicrobial agents that eventually resulted in failure of antibiotic therapeutic protocols (Blair et al., 2015). Furthermore, the overuse of antibiotics in animal husbandry as growth promoters could be a potential source of bacterial resistance through dissemination of resistant microbes from intestinal microbiota of livestock that contaminate the surrounding environment and enhance the transmission of resistant genes to autochthonous bacteria (resident microbes) (McEwen and Collignon, 2018).

\section{Antimicrobial Resistance and Biofilm Formation of $\boldsymbol{E}$. coli Isolates}

The development of antimicrobial resistance among the pathogenic bacteria poses a problem of high concern. Table 3 shows that E. coli isolates were highly resistant to amoxicillinclavulanate, ampicillin, cefotaxime and ceftazidime with percentages of $89.4 \%, 89.4 \%, 100.0 \%$ and $100.0 \%$ respectively. In addition, the isolates were highly sensitive to chloramphenicol, ciprofloxacin and tetracycline with percentage of $100.0 \%, 100.0 \%$ and $93.6 \%$ respectively. Nearly similar results were obtained by Nobili $\boldsymbol{e t}$ al. (2016) where he reported a significantly higher percentage $(100 \%)$ resistance to amoxicillin-clavulanic acid. Thaker et al. (2012) recorded higher resistance rate to ampicillin (100 \%). While Bhardwaj et al. (2021) found complete resistance against amoxicillin and ampicillin. Shalaby et al. (2019) found that all E.coli isolates exhibited susceptibility to chloramphenicol, ciprofloxacin, and tetracycline (except for one isolate that was resistant to ciprofloxacin). In addition, the results reported by Tadesse $\boldsymbol{e t}$ al. (2018) were relatively similar to this study where the in vitro growth $E$. coli was restrained by ciprofloxacin and tetracycline.

The multiple antibiotic resistance (MAR) index, an index describing the resistance of isolates to different antibiotics, was calculated for each isolate as described in the materials and methods section. Values for the MAR index were 0.2 (i.e., an isolate being resistant to two 
Table 1. Incidence of $E$. coli in examined market raw milk samples

\begin{tabular}{lccc}
\hline No. of samples & \multicolumn{3}{c}{ Positive samples } \\
\cline { 2 - 4 } & No. & \% of total \\
\hline $\mathbf{1 0 0}$ & 47 & $(47.0 \%)$ \\
\hline
\end{tabular}

Table 2. Serological identification of $E$. coli strains isolated from market raw milk samples

\begin{tabular}{lcc}
\hline Serogroup & No. & \% of total \\
\hline $\mathbf{O 2 5}$ & 5 & $(10.6 \%)$ \\
$\mathbf{O 2 6}$ & 10 & $(21.3 \%)$ \\
$\mathbf{O 4 4}$ & 4 & $(8.5 \%)$ \\
$\mathbf{O 5 5}$ & 7 & $(14.9 \%)$ \\
$\mathbf{O 7 8}$ & 2 & $(4.3 \%)$ \\
$\mathbf{O 8 6}$ & 2 & $(4.3 \%)$ \\
$\mathbf{O 1 1 4}$ & 3 & $(6.4 \%)$ \\
$\mathbf{O 1 1 9}$ & 3 & $(6.4 \%)$ \\
$\mathbf{O 1 2 5}$ & 3 & $(8.5 \%)$ \\
$\mathbf{O 1 2 7}$ & 4 & $(4.3 \%)$ \\
$\mathbf{O 1 5 8}$ & 2 & $(4.3 \%)$ \\
$\mathbf{O 1 6 8}$ & 2 & $(6.4 \%)$ \\
Total & 3 & $(100.0 \%)$ \\
\hline
\end{tabular}

Table 3. Antibiogram pattern of identified $E$. coli isolates $(n=47)$

\begin{tabular}{lcccc}
\hline Antimicrobial & $\begin{array}{c}\text { Concentrati } \\
\text { on }(\boldsymbol{\mu g})\end{array}$ & \multicolumn{3}{c}{ No. of isolates (\%) } \\
\cline { 3 - 5 } & & Resistant & Intermediate & Susceptible \\
\hline Amoxicillin-clavulanate & $\mathbf{2 0 / 1 0} \boldsymbol{\mu g}$ & $42(89.4 \%)$ & $0(0.0 \%)$ & $5(10.6 \%)$ \\
Ampicillin & $\mathbf{1 0} \boldsymbol{\mu g}$ & $42(89.4 \%)$ & $0(0.0 \%)$ & $5(10.6 \%)$ \\
Cefotaxime & $\mathbf{3 0} \boldsymbol{\mu g}$ & $47(100.0 \%)$ & $0(0.0 \%)$ & $0(0.0 \%)$ \\
Ceftazidime & $\mathbf{3 0} \boldsymbol{\mu g}$ & $47(100.0 \%)$ & $0(0.0 \%)$ & $0(0.0 \%)$ \\
Chloramphenicol & $\mathbf{3 0} \boldsymbol{\mu g}$ & $0(0.0 \%)$ & $0(0.0 \%)$ & $47(100.0 \%)$ \\
Ciprofloxacin & $\mathbf{5} \boldsymbol{\mu g}$ & $0(0.0 \%)$ & $0(0.0 \%)$ & $47(100.0 \%)$ \\
Kanamycin & $\mathbf{3 0} \boldsymbol{\mu g}$ & $9(19.1 \%)$ & $25(53.2 \%)$ & $13(27.7 \%)$ \\
Nalidixic acid & $\mathbf{3 0} \boldsymbol{\mu g}$ & $0(0.0 \%)$ & $29(61.7 \%)$ & $18(38.3 \%)$ \\
Streptomycin & $\mathbf{1 0} \boldsymbol{\mu g}$ & $20(42.6 \%)$ & $20(42.6 \%)$ & $7(14.9 \%)$ \\
Tetracycline & $\mathbf{3 0} \boldsymbol{\mu g}$ & $3(6.4 \%)$ & $0(0.0 \%)$ & $44(93.6 \%)$ \\
\hline
\end{tabular}


out of the 10 antibiotics tested), 0.4 (resistance to 4 out of the 10 antibiotics tested), 0.5 (resistance to 5 out of the 10 antibiotics tested) and 0.6 (resistance to 6 out of the 10 antibiotics tested) with percentages of $10.6 \%, 53.2 \%$, $23.4 \%$ and $12.8 \%$, respectively.

$E$. coli has also been shown to be a significant reservoir of genes coding for antimicrobial drug resistance and therefore is a useful indicator for resistance in bacterial communities (Ars'enePloetze et al., 2018; Katakweba et al., 2018).

In the present study, $89.4 \%$ of $E$. coli isolates showed resistance to more than three classes of antimicrobials (Table 4).

Biofilm formation is one of the most important virulence factors that protect microbes from antimicrobial drugs and treatment (Olsen, 2015). The ability of spoilage and pathogenic bacteria to adhere onto food surfaces and form biofilms serve as a persistent source of food contamination that threatens food safety and causes huge losses to the food industry (Tezel and Şanlıbaba, 2018).

Table 5 revealed that $78.7 \%$ of E. coli isolates were non-biofilm producers, $6.4 \%$ were weak biofilm producers, $14.9 \%$ were moderate biofilm producers and none of isolates was strong biofilm producers. Nearly similar studies of Milanov et al. (2015) who recorded that 19 (76\%) isolates of E.coli did not produce biofilm and $6(24 \%)$ were classified as weak biofilm producers.

Musa et al. (2019) found that 6 out of 15 (40\%) of E. coli were strong biofilm producers, 2 out of 15 were moderate biofilm producers (13.3\%), 4 out of 15 (26.7\%) were weak biofilm producers and only three isolates $(20 \%)$ were non-biofilm producers.

Bhardwaj et al. (2021) reported that out of 32 E.coli isolates tested, 4 were strong formers, 11 were moderate, 15 were weak producers and 2 non-producers.

Da Silva Chagas et al. (2017) recorded that $11(55 \%)$ of 20 biofilm producing strains were identified as E.coli, and all strains were classified as strong biofilm producers.

Cruz-Soto et al. (2020) found that 26 $(76.5 \%)$ of the isolates formed biofilm to some degree, while the remaining $8(23.5 \%)$ did not form biofilm. Of the biofilm-forming isolates, 7 were classified as strong and moderate biofilm producers and 12 as a weak one.

This study provides further evidence that raw cow milk is a potential source of E.coli r some of which are associated with serotypes clinically significant bearing biofilm formation ability and multiple antibiotic resistance that may raise public health concern due to the potential human infection and antimicrobial resistance dissemination throughout food system.

Table 4. Multi drug resistance pattern and multiple antibiotic resistance index of identified $E$. coli isolates $(\mathrm{n}=47)$

\begin{tabular}{|c|c|c|c|c|c|c|c|c|c|c|}
\hline \multirow{3}{*}{$\begin{array}{l}\text { No. of } \\
\text { isolates }\end{array}$} & \multirow{2}{*}{\multicolumn{2}{|c|}{$\begin{array}{c}\text { Multi drug } \\
\text { resistance (MDR) }\end{array}$}} & \multicolumn{8}{|c|}{ Multiple antibiotic resistance (MAR) } \\
\hline & & & \multicolumn{2}{|r|}{0.2} & \multicolumn{2}{|c|}{0.4} & \multicolumn{2}{|r|}{0.5} & \multicolumn{2}{|r|}{0.6} \\
\hline & No. & $\%$ & No. & $\%$ & No. & $\%$ & No. & $\%$ & No. & $\%$ \\
\hline 47 & 42 & $(89.4 \%)$ & 5 & $(10.6 \%)$ & 25 & $(53.2 \%)$ & 11 & $(23.4 \%)$ & 6 & $(12.8 \%)$ \\
\hline
\end{tabular}

Table 5. Ability of E. coli strains isolated from market raw milk samples to form biofilm

\begin{tabular}{ccccccccc}
\hline $\begin{array}{c}\text { No. of } \\
\text { isolates }\end{array}$ & \multicolumn{8}{c}{ Degree of biofilm formation } \\
\cline { 2 - 10 } & \multicolumn{2}{c}{ None } & \multicolumn{2}{c}{ Weak } & \multicolumn{2}{c}{ Moderate } & \multicolumn{2}{c}{ Strong } \\
\cline { 2 - 10 } & No. & $\%$ & No. & $\%$ & No. & $\%$ & No. & $\%$ \\
\hline 47 & 37 & $(78.7 \%)$ & 3 & $(6.4 \%)$ & 7 & $(14.9 \%)$ & 0 & $(\mathbf{0 . 0 \%})$ \\
\hline
\end{tabular}




\section{REFERENCES}

Abd El-Maaboud (2014). Studies on some food poisoning organisms in milk and some locally produced soft cheese. M.V.Sc. Thesis, Fac. Vet. Med. Sadat City Univ.

Abike, T.O., O.A. Olufunke and K.D. Oriade (2015). Prevalence of multiple diseases surveillance and response. Antibiotic resistant Escherichia coli serotypes in cow, raw milk samples and traditional dairy products in Osun State, Nigeria. British Microbiol. Res. J. BMR J., 5 (2):117-125.

Addis, M.F., A. Tanca, S. Uzzau, G. Oikonomou, R.C. Bicalho and P. Moroni (2016). The bovine milk microbiota: Insights and perspectives from-omics studies. Molecular Bio Systems, 12(8): 2359-2372.

Ahmed, A.M. and S.S. Sallam (1991) Prevalence of Escherichia coli serotypes in raw milk and some dairy products. Assiut Vet. Med. J., 25: 93-97.

Alexander, M. and V. Prado (2003). Detection of Shiga toxin producing Escherichia coli in food. Expert Rev. Mol. Diagn., 3(1):105-115.

Altalhi, A.D. and S.A. Hassan (2009). Bacterial quality of raw milk investigated by Escherichia coli and isolates analysis for specific virulence -gene markers. Food Control, 20 (10): 913-917.

Angulo, F., J.T. Lejeune and P.J. Rajala-Schultz (2009). Unpasteurized milk: A continued public health threat. Clin. Infect. Dis., 48 (1): 93-100.

APHA (2004) Standard Methods for the Examination of Dairy Products. $17^{\text {th }}$ Ed., Ame. Public Health Assoc., Washington.

Ars`ene-Ploetze, F., O. Chiboub, D. Li'evremont, J. Farasin, K. C. Freel, S. Fouteau and V. Barbe (2018). Adaptation in toxic environments: comparative genomics of loci carrying antibiotic resistance genes derived from acid mine drainage waters. Environ. Sci. and Pollution Res., 25 (2): 1470-1483.

Bhardwaj, D.K., N.K. Taneja, D.P. Shivaprasad, A. Chakotiya, P. Patel, P. Taneja and M.G.
Sanal (2021). Phenotypic and genotypic characterization of biofilm forming, antimicrobial resistant, pathogenic Escherichia coli isolated from Indian dairy and meat products. Int. J. Food Microbiol., 336: 108899.

Blair, J.M., M.A. Webber, A.J. Baylay, D.O. Ogbolu and L.J. Piddock (2015). Molecular mechanisms of antibiotic resistance. Nature Reviews Microbiol., 13 (1):42-51.

Chye, F.Y., A. Abdullah and M.K. Ayob (2004). Bacteriological quality and safety of raw milk in Malaysia. Food Microbiol., 21: 535541.

CLSI (2017). Performance Standards for Antimicrobial Susceptibility Testing. 474 M100-S27. Clinical and Laboratory Standards Inst., Wayne, PA.

Corcoran, M., D. Morris, N. De Lappe, J. O'Connor, P. Lalor, P. Dockery and M. Cormican (2014). Commonly used disinfectants fail to eradicate Salmonella enterica biofilms from food contact surface materials. Appl. Environ. Microbiol., 80: 1507-1514.

Cruz-Soto, A.S., V. Toro-Castillo, C.O. Munguía-Magdaleno, J. E. Torres-Flores, L. E. Flores-Pantoja, P. D. Loeza-Lara and R. Jiménez-Mejía (2020). Genetic relationships, biofilm formation, motility and virulence of Escherichia coli isolated from bovine mastitis. Rev. Mex. Cienc. Pecu., 11(1): 167182.

Da Silva Chagas, L.G., P. de Castro Melo, S.C. Brasão, G.B.R. Silvestre, E.C. Guimarães and A.M.C. Lima (2017). Evaluation of biofilm formation by bacterial strains isolated from milking equipment and milk samples from cows with mastitis. Semina: Ciências Agrárias, 38 (4): 1887-1895.

El-Bagory, A.M., A.M. Hammad and S.M. Alzahraa (2016). Prevalence of Coliforms, antibiotic resistant Coliforms and E. coli serotypes in raw milk and some varieties of raw milk cheese in Egypt. Nutr. Food Technol., $2: 1$.

El-Nahas, A.W., H.A. Mohamed, H.A. El Barbary and H.S. Mohamed (2015). Incidence of 
E.coli in raw milk and its products. Benha Vet. Med. J., 29 (1): 112-117.

El-Prince, E., M. Sayed, M. Farghaly and A.M. Abdel-Rahman (2010) Investigation of milk and some dairy products for fecal pollution indicators. Assiut Vet. Med. J., 56 (127): 96107.

El-Zamkan, M.A. and K.G.A. Hameed (2018). Molecular Characterization of Non-O157 Shiga Toxin-producing E. coli detected in raw milk and some dairy products. Microbiol. Res. J. Int., 1-14

Frye, J.G. and P.J. Fedorka-Cray (2007). Prevalence, distribution and characterization of ceftiofur resistance in Salmonella enterica isolated from animals in the USA from 1999 to 2003. Int. J. Antimicrob. Agents, 30: 134142.

Garedew, L., A. Berhanu, D. Mengesha and G. Tsegay (2012). Identification of gramnegative bacteria from critical control points of raw and pasteurized cow milk consumed at Gondar town and its suburbs, Ethiopia. BMC Public Health, 12 (1):1-7.

Hall-Stoodley, L., J.W. Costerton and P. Stoodley (2004). Bacterial biofilms: From the natural environment to infectious diseases. Nat. Rev. Microbiol., 2: 95-108.

Jayarao, B.M. and D.R. Henning (2001). Prevalence of foodborne pathogens in bulk tank milk. J. Dairy Sci., 84: 2157-2162.

Kalkwarf H.J., J.C. Khoury and B.P. Lanphear (2003). Milk intake during childhood and adolescence, adult bone density and osteoporotic fracture in US women. Ame. J. Clin. Nutr., 77 (1): 257-265.

Katakweba, A.A., A.P. Muhairwa, A.M. Lupindu, P. Damborg, J. T. Rosenkrantz, U. M. Minga and J. E. Olsen (2018). First report on a randomized investigation of antimicrobial resistance in fecal indicator bacteria from Livestock, Poultry, and humans in Tanzania. Microbial Drug Resistance, 24 (3): 260-268

Khafagy, A., H. Eid, F. Youssif and N. E. H. Eid (2017). Escherichia Coli isolated from raw milk at North Sinai Governorate. Suez Canal Vet. Med. J. SCVMJ, 22(2): 121-131.

Khayal, A.A. and O.M. Ragia (2013). Biochemical and microbiological evaluation of fermented camel milk. New York Sci. J., 6: 74-79.

Kok, T., D. Worswich and E. Gowans (1996). Some serological techniques for microbial and viral infections. In Practical Medical Microbiology (Collee, J.; Fraser, A.; Marmion, B. and Simmons, A., eds.), 14th Ed., Edinburgh, Churchill Livingstone, UK.

Koraney, A.A. (2016). Molecular study on multiple antibiotic resistance of some bacteria isolated from food of animal origin in Egyptian Markets. A Thesis presented for the MVS in Vet. Med. Sci. Microbiol., BeniSuif Univ., Fac. Vet. Med., Dept. Bact., Immunol. and Mycol.

Krumperman, P.H. (1983). Multiple antibiotic resistance indexing of Escherichia coli to identify high-risk sources of fecal contamination of foods. Appl. Environ. Microbiol., 46:165-170.

Lamey, A.E., A.M. Ammar, E.R. Zaki, N. Khairy, B.S. Moshref and M.K. Refai (2013). Virulence factors of Escherichia coli isolated from recurrent cases of clinical and subclinical mastitis in buffaloes. Int. J. Microbiol. Res., 4(1): 86-94.

Leedom, J.M. (2006). Milk of nonhuman origin and infectious diseases in humans. Clinc. Infect. Dis., 43: 610-615.

Marshall, T.A., S.M. Levy, B. Broffit, J.J. Warren, J.M. Eichenberger- Glimore, T.L. Bruns and P.J. Stumbo (2003). Dental caries and beverage consumption in young children. Pediatrics, 112(3):184-191.

McEwen, S.A. and P.J. Collignon (2018). Antimicrobial Resistance: A one-health perspective. Microbiol. Spectrum, $6: 2$.

Meshref, A.M.S. (2013). Bacteriological quality and safety of raw cow's milk and fresh cream. Slovenian Vet. Res., 50 (1): 21-30.

Mezyed, E.M., E.M. Sharaf and N.A. Abou ElRoos (2008). Occurrence of some enteric 
pathogens in raw milk and some dairy products. Vet. Med. J. Giza, 56: 29-36.

Milanov, D., B. Prunić, M. Velhner, D. Todorović and V. Polaček (2015). Investigation of biofilm formation and phylogenetic typing of Escherichia coli strains isolated from milk of cows with mastitis. Acta Veterinaria-Beograd, 65 (2): 202-216.

Monte, J., A. Abreu, A. Borges, L. Simões and M. Simões (2014). Antimicrobial activity of selected phytochemicals against Escherichia coli and Staphylococcus aureus and their biofilms. Pathogens, 3:473-498.

Musa, M.D., R.S. Salman and A.D. Mutar (2019). Phylogenetic Background, biofilm and antibiogram profile of E. coli Isolated from raw milk soled in the local markets at Al-Nasiriyah City-Iraq. Int. J. Pharma. Res., 11: 1 .

Nepal, G. and S. Bhatta (2018) Self-medication with antibiotics in who Southeast Asian region: A systematic review, Cureus, $10: 4$.

Newell, D.G., M. Koopmans, L. Verhoef, E. Duizer, A. Aidara-Kane, A. Sprong and $\mathrm{H}$. Kruse (2010). Food-borne diseases - the challenges of 20 years ago still persist while new ones continue to emerge. Int. J. Food Microbiol., 139: 3-15.

Ngaywa, C., G.O. Aboge, G. Obiero, I. Omwenga, N. Ngwili, G. Wamwere and B. Bett (2019). Antimicrobial resistant Escherichia coli isolates detected in raw milk of livestock in pastoral areas of northern Kenya. Food Control, 102:173-178.

Nobili, G., I. Franconieri, M.G. Basanisi, G. La Bella, R. Tozzoli, A. Caprioli and G. La Salandra (2016). Short communication: Isolation of shiga toxin-producing Escherichia coli in raw milk and mozzarella cheese in southern Italy. J. Dairy Sci., 99 (10): 7877-7880.

Oliver, S.P., K.J. Boor, S.C. Murphy and S.E. Murind (2009). Food safety hazard associated with consumption of raw milk. Food Born Pathogen Dis., 6(7): 793-806.
Olsen, I. (2015). Biofilm-specific antibiotic tolerance and resistance. Eur. J. Clin. Microbiol. Infect. Dis., 34:877-886.

Peterson, E. and P. Kaur (2018) Antibiotic resistance mechanisms in bacteria: relationships between resistance determinants of antibiotic producers, environmental bacteria, and clinical pathogens. Front. Microbiol., 9:2928

Rashid, M., S.K. Kotwal, M.A. Malik and M. Singh (2013). Prevalence, genetic profile of virulence determinants and multidrug resistance of Escherichia coli isolates from foods of animal origin. Vet. World, 6 (3): $139-142$.

Reinthaler, F.F., G. Feierl, H. Galler, D. Haas, E. Leitner , F. Mascher and E. Marth (2010). ESBL producing E. coli in Austrian sewage sludge. Water Res., 44 (6): 1981-1985.

Rzewuska, M., M. Czopowicz, M. Kizerwetter'Swida, D. Chrobak, B. Błaszczak and M. Binek (2015). Multidrug resistance in Escherichia coli strains isolated from infections in dogs and cats in Poland. Sci. World J., (2007-2013)

Shalaby, H.Y., K. Baraka, M.S. Ibrahim and E.M. Khalaf (2019). Characterization of bacterial pathogens associated with milk microbiota in Egypt. Afri. J. Microbiol. Res., 13(28): 580-608.

Sobeih, A.M.K., I.I. Al-Hawary and I.M. Aman (2002). Microbiological quality of milk and ice cream sold in Kafr El-Sheikh and ElGharbia governorates. Minufyia Vet. J., 2(1): 79-89

Soomro, A.H., M.A. Arain, M. Khaskheli and B. Bhutto (2002). Isolation of Escherichia coli from raw milk and milk products in relation to public health sold under market conditions at Tandojam. Pak. J. Nutr., 1(3): 151-152

Stepanovic, S., G. Vukovic, I. Dakic, B. Savic and M. Svabic-Vlahovic (2000). A modified micro titer plate test for quantification of staphylococcal biofilm formation. J. Microbiol. Methods, 40: 175-179

Tadesse, H.A., N.B. Gidey, K. Workelule, H. Hailu, Gidey S, A. Bsrat and H. Taddele (2018). Antimicrobial resistance profile of $E$. 
coli isolated from raw cow milk and fresh fruit juice in Mekelle, Tigray, Ethiopia. Vet. Med. Int.

Tasci, F. (2011). Microbiological and chemical properties of raw milk consumed in Burdur. J. Anim. Vet. Adv., 10: 635-641.

Tezel, B.U. and P. Sanlibaba (2018). A Major Concern in Food Industry. Contamination Reservoir, Bacterial Biofilm. Science within Food: Up-to-date Advances on Research and Educational Ideas, 1-10. https://www. researchgate. net/ publication/322745857.

Thaker, H.C., M.N. Brahmbhatt, J.B. Nayak (2012). Study on occurrence and antibiogram pattern of $E$. coli from raw milk samples in Anand, Gujarat, India. Vet. World, 5(9):556.
Van Boeckel T.P., C. Brower, M. Gilbert, B.T. Grenfell, S.A. Levin, T.P. Robinson, A. Teillant and R. Laxminarayan (2015). Global trends in antimicrobial use in food animals. Proc. Nat. Acad. Sci. United States Ame., 112 (18): 5649-5654.

Wenz, J.R., G.M. Barington, F.B. Garry, R.P. Ellis and R.J. Magnuson (2006). Escherichia coli isolates serotypes, genotypes and virulence genes and clinical coliform mastitis severity. J. Dairy Sci., 89: 3408-3412

Xu, Z.Q., M.T. Flavin and J. Flavin (2014). Combating multidrug-resistant Gram-negative bacterial infections. Expert Opin. Invest. Drugs, 23 (2):163-182.

\section{أنماط مقاومة المضادات الحيوية وتكوين البيوفيلم لعترات الايشريكية القولونية المعزولة من لبن السوق الخام بمدينة الزقازيق الباني \\ آية رياض محمد ـ عصمت ابراهيم السعيا ـ صلاح فتحي عبدالعال ـ رانيا محمد كمال \\ قسم مر اقبة الأغذية ـ كلية الطب البيطري - جامعة الزقازيق ــ مصر مئر}

في هذه الدراسة، تم جمع مائة عينة من حليب البقر الخام بشكل عشوائي من متاجر وأسواق الألبان المختلفة في مدينة

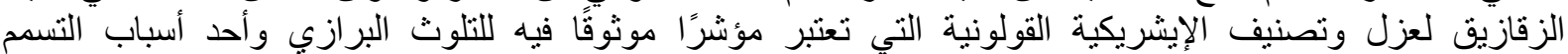

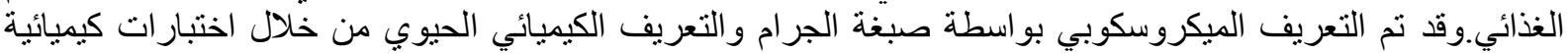



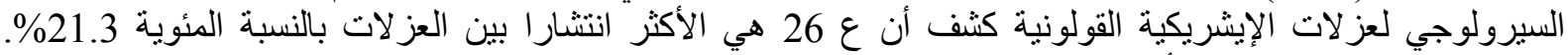

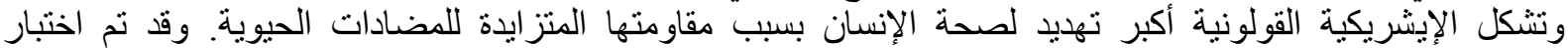

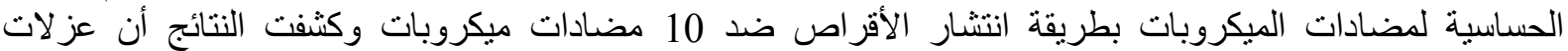

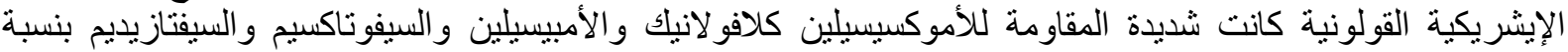
و 89.4 و و89.4 \% و 100.0 \% و و100.0 \% \% على التو الي. وكانت شديدة الحساسية للكلور امفينيكول و السييرو فلوكساسين

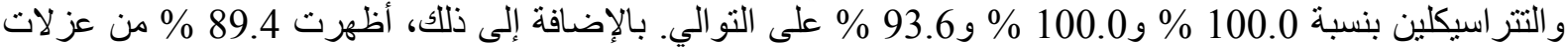

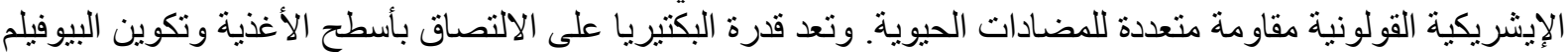

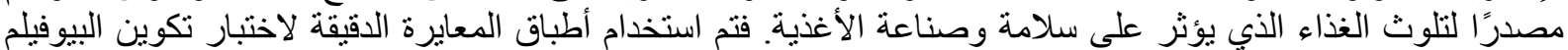

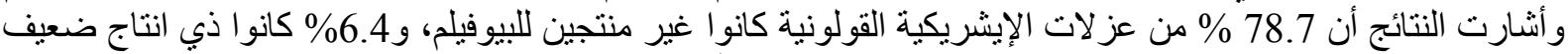

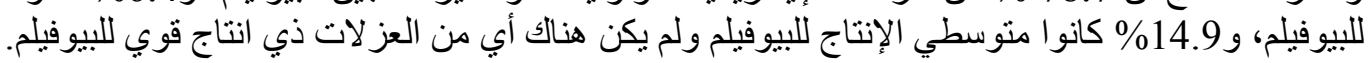

